\title{
Community ecology of the metazoan parasites of Brazilian sardinella, Sardinella brasiliensis (Steindachner, 1879) (Actinopterygii: Clupeidae) from the coastal zone of the State of Rio de Janeiro, Brazil
}

\author{
Moreira, J. ${ }^{a}$, Paschoal, F. ${ }^{b}$, Cezar, AD. ${ }^{c}$ and Luque, JL. ${ }^{d *}$ \\ ${ }^{a}$ Curso de Pós-Graduação em Ciências Veterinárias, Departamento de Parasitologia Animal, Universidade Federal Rural do \\ Rio de Janeiro - UFRRJ, BR 465, Km 7, CEP 23890-000, Seropédica, RJ, Brazil \\ bPrograma de Pós-Graduação em Biologia Animal, Universidade Federal Rural do Rio de Janeiro - UFRRJ, \\ BR 465, Km 7, CEP 23890-000, Seropédica, RJ, Brazil \\ ${ }^{\mathrm{c}}$ Centro de Estudos e Pesquisas Biológicas - CEPBio, Universidade Castelo Branco - UCB, \\ Avenida Santa Cruz, 1631, Realengo, CEP 21710-250, Rio de Janeiro, RJ, Brazil \\ dDepartamento de Parasitologia Animal, Universidade Federal Rural do Rio de Janeiro - UFRRJ, \\ CP 74540, CEP 23851-970, Seropédica, RJ, Brazil \\ *e-mail: luqueufrrj@gmail.com
}

Received: January 17, 2014 - Accepted: March 15, 2014 - Distributed: August 31, 2015

(With 1 figure)

\begin{abstract}
Between March 2010 and August 2011 were necropsied 100 specimens of Sardinella brasiliensis (Steindachner,

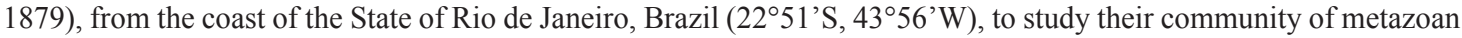
parasites. All specimens of $S$. brasiliensis were parasitized by at least one species of metazoan parasite, with mean of $68.7 \pm 71.2$ parasites/fish. Eleven species were collected: 3 digeneans, 1 monogenean, 2 cestodes, 3 nematodes and 2 copepods. The digenean Myosaccium ecaude Montgomery was the most abundant, prevalent, and dominant species, representing $72.7 \%$ of metazoan parasites collected, showing positive correlation between host's total length and parasite abundance. Total parasite abundance was positively correlated with host's total length. Three pairs of adult endoparasites showed significant positive association and covariation. The parasite community of $S$. brasiliensis showed dominance by digeneans. Sardinella brasiliensis represents new host record for most found parasite species.
\end{abstract}

Keywords: parasite ecology, community structure, Clupeidae, Sardinella brasiliensis, Brazil.

\section{Ecologia da comunidade dos metazoários parasitos da sardinha Sardinella brasiliensis (Steindachner, 1879) (Actinopterygii: Clupeidae) do litoral do Estado do Rio de Janeiro, Brasil}

\begin{abstract}
Resumo
Entre março de 2010 e agosto de 2011 foram necropsiados 100 espécimes de Sardinella brasiliensis (Steindachner,

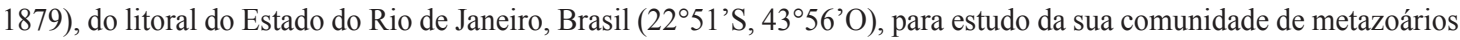
parasitos. Todos os espécimes de $S$. brasiliensis estavam parasitados por pelo menos uma espécie de metazoário, com média de 68,7 $\pm 71,2$ parasitos/peixe. Onze espécies foram coletadas: 3 digenéticos, 1 monogenético, 2 cestóides, 3 nematóides e 2 copépodes. O digenético Myosaccium ecaude Montgomery foi a espécie mais abundante, prevalente, e dominante, representando $72,7 \%$ dos metazoários parasitos, apresentando correlação positiva entre o comprimento total do hospedeiro e a abundância parasitária. A abundância parasitária total foi positivamente correlacionada com o comprimento total do hospedeiro. Três pares de endoparasitos adultos apresentaram associação e covariação positivas significativas. A comunidade parasitária de S. brasiliensis apresentou dominância por digenéticos. Sardinella brasiliensis representa novo registro de hospedeiro para a maioria dos parasitos encontrados.
\end{abstract}

Palavras-chave: ecologia parasitária, estrutura comunitária, Clupeidae, Sardinella brasiliensis, Brasil.

\section{Introduction}

The Brazilian sardinella, Sardinella brasiliensis (Steindachner) is a marine finfish that inhabits coastal waters from Rio de Janeiro to south Brazil, always forming large schools. This species feeds mainly of the planktonic organisms filtered by gill rakers (Figueiredo and Menezes, 1978). It's the most important marine fishery resource of Brazil, in volume production, with landings concentrated in the States of Rio de Janeiro, São Paulo e Santa Catarina, 
contributing to world food resources in two ways: directly, through actual consumption (fresh, frozen or processed) and indirectly, by providing products used for animal feeds and fertilizers or by serving as bait to catch other fishes. (Paiva, 1997; Whitehead, 1985).

In Brazil, the parasitic fauna of clupeid fishes is poorly known, with most studies of taxonomy origin, performed by Vaz and Pereira (1930), Kohn and Bührnheim (1964), Travassos et al. (1967), Feijó et al. (1979), Wallet and Kohn (1987), Fabio (1988), Fernandes and Goulart (1989), with descriptions and records of digenetic trematodes; Kohn and Santos (1988) and Santos and Kohn (1992) for monogeneans; Palm (1997) and Rodrigues et al. (1990) for cestodes; Vicente et al. (1985) and Feijó et al. (1979) for nematodes; Montú (1980) and Amado and Falavigna (1996) for copepods. Studies regarding to ecological aspects were performed by Luque et al. (2000) and Tavares et al. (2004), on the parasitic fauna of Harengula clupeola (Cuvier) and S. brasiliensis, and Brevoortia aurea (Spix and Agassiz), respectively.

In this report, we analyze the composition and structure of the metazoan parasite communities of S. brasiliensis from the coastal zone of the State of Rio de Janeiro, Brazil.

\section{Material and Methods}

Between March 2010 and August 2011, 100 specimens of $S$. brasiliensis were necropsied, from the coast of Cabo Frio, Rio de Janeiro, Brazil $\left(22^{\circ} 51>\mathrm{S}, 43^{\circ} 56>\mathrm{O}\right)$, to study their community of metazoan parasites. Fishes were identified according to Figueiredo and Menezes (1978). The analysis included only parasite species with prevalence higher than 10\% (Bush et al., 1990).

The variance-to-mean ratio of parasite abundance (index of dispersion) and the discrepancy index, computed using the program Quantitative Parasitology 3.0 (Rózsa et al., 2000), were used to detect distribution patterns of the infrapopulations (Poulin, 1993). The dominance frequency and the relative dominance (number of specimens of one species/total number of specimens of all species in the infracommunity) of each parasite species were calculated according to Rohde et al. (1995). The parasite species diversity was calculated using the Brillouin index $(H)$, because each fish analyzed corresponded to a fully censused community (Zar, 1996). The Spearman's rank correlation coefficient $r s$ was calculated to determine possible correlations between the total length of hosts and parasite abundance. Pearson's correlation coefficient $r$ was used to indicate the relationship between the host's total length and parasite prevalence, with previous arcsine transformation of the prevalence data (Zar, 1996). The effect of host sex on abundance and prevalence of parasites was tested using the $Z c$ (normal) approximation to the Mann-Whitney test and the Fisher exact test, respectively. Parasite species diversity was calculated using the Brillouin's index $(H)$ (Zar, 1996). The probable variation of diversity in relation to host sex (Mann-Whitney test) and to host total length (Spearman's rank correlation coefficient) was tested. Possible interspecific association between concurrent species was determined using the chi-square test. Possible covariation among the abundance of concurrent species was analyzed using the Spearman's rank correlation coefficient. The ecological terminology used follows Bush et al. (1997). Statistical significance level was evaluated at $\mathrm{p} \leq 0.05$. Voucher specimens of helminths were deposited in the Helminthological Collection of Institute Oswaldo Cruz (CHIOC), Rio de Janeiro, Brazil; copepods were deposited in the Carcinological Collection of National Museum of Rio de Janeiro (MNRJ), Brazil.

\section{Results}

The average total length of the fish was $12.7-24.8$ $(20.4 \pm 1.91) \mathrm{cm}$, and the weight was $25-120(77.6 \pm 19.8) \mathrm{g}$. The average total length of male $(20.6 \pm 1.2, n=79)$ and female $(20 \pm 2.8, n=21)$ fishes in the studied sample were significantly different $(t=-2.890, P=0.005)$.

\subsection{Component community}

Eleven species of metazoan parasites were collected (Table 1). Sardinella brasiliensis is a new host record for most of these species with exceptions made for the digeneans Myosaccium ecaude Montgomery and Parahemiurus merus Price (Luque et al., 2000), and for the copepod Clavellisa ilishae Pillai (Moreira et al., 2013). The digenetic trematode $M$. ecaude was the most abundant, prevalent, and dominant species, representing $72.7 \%$ of metazoan parasites collected with greatest values of mean relative dominance and frequency of dominance (Table 2).

Adult endoparasites represented $98.98 \%$ of all parasites collected, larval endoparasites amounted to $0.64 \%$, and ectoparasites made up $0.38 \%$. All parasites of S. brasiliensis had the typical aggregated pattern of distribution, except the cestode Callitetrarhynchus gracilis Rudolphi that showed dispersion index lower than 1 , indicating a uniform pattern of distribution (Table 3). Only M. ecaude showed positively correlation between host's total length and parasite abundance ( $r s=0.197, p=0.049)$. The host's total length was not correlated with the prevalence of any species. The sex of hosts did not influence prevalence and abundance of any parasite species.

\subsection{Infracommunities}

All specimens of $S$. brasiliensis were parasitized by at least one parasite species. A total of 6,866 individual parasites were collected, with mean of $68.7 \pm 71.2$ parasites/ fish. Positive correlations were detected between parasite abundance and host's total length $(r s=0.222, p=0.026)$, but the host's total length was not correlated with parasite species richness $(r s=0.193, p=0.055)$. Six hosts $(6 \%)$ showed infection with one parasite species, and $48(48 \%)$, $36(36 \%), 7(7 \%)$ e $3(3 \%)$ had multiple infections with 2, 3, 4, 5 parasite species, respectively (Figure 1). Mean parasite species diversity $(H=0.545 \pm 0.228)$ was not correlated with host's total length $(r s=0.168, p=0.094)$ and no significant differences in parasite diversity were observed between male $(H=0.529 \pm 0.239)$ and female $(H=0.605 \pm 0.175)$ fishes $\left(Z_{c}=-1.292, p=0.196\right)$. 
Table 1. Prevalence, mean intensity, mean abundance, and site of infection of metazoan parasites of Sardinella brasiliensis from the coastal zone of the State of Rio de Janeiro.

\begin{tabular}{|c|c|c|c|c|}
\hline Parasites & Prevalence (\%) & Mean intensity & $\begin{array}{c}\text { Mean } \\
\text { abundance }\end{array}$ & $\begin{array}{c}\text { Site of } \\
\text { infection/ } \\
\text { infestation }\end{array}$ \\
\hline \multicolumn{5}{|l|}{ Digenea } \\
\hline Parahemiurus merus CHIOC No 37932 & 94 & $18.9 \pm 15.7$ & $17.8 \pm 15.9$ & Stomach \\
\hline Myosaccium ecaude CHIOC No 37933 & 98 & $50.9 \pm 61.6$ & $49.9 \pm 61.4$ & Stomach \\
\hline Prodistomum gracile CHIOC No 37935 & 13 & $2.2 \pm 2.0$ & $0.3 \pm 1.0$ & Intestine \\
\hline \multicolumn{5}{|l|}{ Monogenea } \\
\hline $\begin{array}{l}\text { Cribomazocraes travassosi } \\
\text { CHIOC N } 37938\end{array}$ & 3 & $1.3 \pm 0.6$ & $0.04 \pm 0.2$ & Gills \\
\hline \multicolumn{5}{|l|}{ Cestoda } \\
\hline $\begin{array}{l}\text { Callitetrarhynchus gracilis (plerocercoid) } \\
\text { CHIOC N } 37936 / 37937\end{array}$ & 15 & $1.1 \pm 0.3$ & $0.2 \pm 0.4$ & Body cavity \\
\hline $\begin{array}{l}\text { Nybelinia } \text { sp. (plerocercoid) } \\
\text { CHIOC N } 37939\end{array}$ & 1 & 1 & $0.01 \pm 0.1$ & Body cavity \\
\hline \multicolumn{5}{|l|}{ Nematoda } \\
\hline $\begin{array}{l}\text { Hysterothylacium sp. (larval) } \\
\text { CHIOC No } 35924\end{array}$ & 13 & $1.8 \pm 1.5$ & $0.2 \pm 0.8$ & Mesenteries \\
\hline $\begin{array}{l}\text { Pseudoterranova sp. (larval) } \\
\text { CHIOC N } 35925\end{array}$ & 1 & 1 & $0.01 \pm 0.1$ & Mesenteries \\
\hline $\begin{array}{l}\text { Raphidascaris sp. (larval) } \\
\text { CHIOC No } 35926 / 35927\end{array}$ & 2 & 1 & $0.02 \pm 0.1$ & Mesenteries \\
\hline \multicolumn{5}{|l|}{ Copepoda } \\
\hline Clavellisa ilishae MNRJ No 23421 & 4 & $2.8 \pm 2.9$ & $0.1 \pm 0.7$ & Gills \\
\hline Nothobolochus cresseyi MNRJ No 24144 & 10 & $1.1 \pm 0.3$ & $0.1 \pm 0.3$ & Gills \\
\hline
\end{tabular}

Table 2. Frequency of dominance and mean relative dominance of metazoan parasites of Sardinella brasiliensis from the coastal zone of the State of Rio de Janeiro.

\begin{tabular}{lccc} 
coastal zone of the State of Rio de Janeiro. & & \\
\multicolumn{1}{c}{ Parasites } & Frequency of dominance & $\begin{array}{c}\text { Frequency of dominance } \\
\text { shared with one or more } \\
\text { species }\end{array}$ & $\begin{array}{c}\text { Mean relative dominance } \\
\text { Parahemiurus merus }\end{array}$ \\
Myosaccium ecaude & 15 & 3 & $0.313 \pm 0.213$ \\
\hline
\end{tabular}

Table 3. Values of variance to mean ratio of parasite abundance (ID) and index of Discrepancy (D) of metazoan parasites of Sardinella brasiliensis from the coastal zone of the State of Rio de Janeiro.

\begin{tabular}{lcc}
\hline \multicolumn{1}{c}{ Parasites } & ID & D \\
\hline Parahemiurus merus & 14.213 & 0.454 \\
Myosaccium ecaude & 75.513 & 0.538 \\
Prodistomum gracile & 3.613 & 0.912 \\
Callitetrarhynchus gracilis & $0.975^{*}$ & 0.850 \\
Hysterothylacium sp. & 2.704 & 0.906 \\
\hline
\end{tabular}

*significant values.

The endoparasites were separated into two groups helminth larval stages (cestodes and nematodes) and adult endoparasites (digeneans) - and were used to determine possible interspecific associations. Ectoparasites (copepods and monogeneans) were not included in this analysis because none of the species of this group showed prevalence higher than $10 \%$. The helminth larval stages pair, C. gracilis Hysterothylacium sp., did not share significant association and covariation $\left(\chi^{2}=0.63, p=0.429 ; r_{s}=-0.083, p=0.412\right)$. The three pairs of endoparasites species M. ecaude-P. merus, M. ecaude-Prodistomum gracile, P. merus - P. gracile, showed positive covariation (Table 4 ). 
Table 4. Concurrent species pairs of endoparasites in Sardinella brasiliensis from the coastal zone of the State of Rio de Janeiro.

\begin{tabular}{lcccc}
\hline \multicolumn{1}{c}{ Parasites } & $\boldsymbol{\chi}^{2}$ & $\boldsymbol{p}$ & $\boldsymbol{r}_{\boldsymbol{s}}$ & $\boldsymbol{p}$ \\
\hline Parahemiurus merus - Myosaccium ecaude & 0.13 & 0.718 & $0.558^{*}$ & $<0.0001$ \\
P. merus - Prodistomum gracile & 0.95 & 0.329 & $0.231^{*}$ & 0.021 \\
M. ecaude - P.gracile & 0.31 & 0.581 & $0.222^{*}$ & 0.026 \\
\hline
\end{tabular}

$\left(\chi^{2}\right)$ Chi-square test; $(r)$ values of Spearman's rank correlation coefficient. $(p)$ significant level. *significant values.

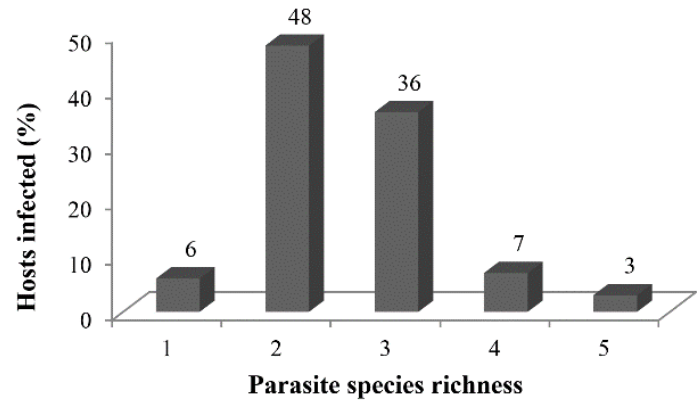

Figure 1. Distribution of species richness in the parasite infracommunities of Sardinella brasiliensis from the coastal zone of the State of Rio de Janeiro.

\section{Discussion}

The parasite community of $S$. brasiliensis showed digenetic trematodes dominance, which was previously reported by Luque et al. (2000) in a quantitative study of clupeid fishes from the coastal zone of the state of Rio de Janeiro. The dominance of digenean endoparasites has been described for several parasite communities of marine fishes from the coastal zone of southeastern Brazil (Luque et al., 1996; Takemoto et al., 1996; Knoff et al., 1997; Luque and Chaves, 1999; Silva et al., 2000; Luque and Alves, 2001; Tavares and Luque, 2004). The feeding of $S$. brasiliensis, which is predominantly composed by zooplanktonic copepods (Schneider and Schwingel, 1999), may favor the transmission of these parasites, since many of them act as intermediate hosts for digeneans.

Regarding to the study previously performed by Luque et al. (2000), the parasite species richness has increased and another important change was the presence of larval stages of helminths that were absent in the previous study, the nematodes Hysterothylacium sp., Pseudoterranova sp. and Raphidascaris sp., and the cestodes $C$. gracilis and Nybelinia sp. These differences may be related to the number of specimens necropsied, changes in coastal ecological features, seasonality, and the lack of studies on the parasites of clupeid fishes in the region. This low infection of larval stages of helminths was also observed in other clupeid fishes by Pérez-Ponce de León et al. (2000), in Mexico. And according to some authors, the presence of larval stages of helminths can be considered as a reflection of the intermediate trophic level of the host (George-Nascimento, 1987; Luque and Poulin, 2004).

The schooling habits of herrings might facilitate the transmission of some ectoparasites with direct life cycle, such as copepods and monogeneans (Luque and Alves, 2001). However, in this study a low prevalence in both taxa was observed, which may have been influenced by host biology, parasite specificity, hydrological conditions or environmental and ecological conditions of the region (Cone and Burt, 1982; Ibagy and Sinque, 1985). The monogenean Cribomazocraes travassosi Kohn and Santos was originally described parasitizing Harengula clupeola, and this paper reports the first occurrence of this species in $S$. brasiliensis, but with a low prevalence as previously mentioned, which may be an indication of the host specificity demonstrated by many monogeneans.

The parasite community of $S$. brasiliensis had the typically aggregated pattern of distribution, with exception made for Callitetrarhynchus gracilis who had an index of dispersion less than 1 , thus indicating a uniform pattern of distribution, which is not a common occurrence in helminths. According to Von Zuben (1997) there are three factors that can lead to a uniform pattern of distribution: (1) mortality of parasites; (2) density dependent processes; and (3) the mortality of the host induced by the parasite (mortality rate positively correlated with parasite charge).

Unlike the pattern previously observed, the parasite abundance was positively correlated with host's total length. According to Polyansky (1961) quantitative and qualitative changes in parasitism are expected with fish growth. Diet, body mass and school formation are factors considered by Polyansky and Bychowsky (1963) as responsible for the number of parasite species harbored by a host. But according to Luque and Alves (2001), generalizations about the influence of host size on the quantitative and qualitative composition of parasitic infracommunities should be avoided.

The absence of correlations between host gender and the prevalence and abundance of the parasite community of S. brasiliensis has been reported before by Luque et al. (2000). However, different patterns have already been observed for other clupeid fishes from the coastal zone of the State of Rio de Janeiro (Luque et al., 2000; Tavares et al., 2004), which suggests a heterogeneous pattern, but additional studies are needed to evaluate the community structure of clupeid fishes in the Neotropical region.

Sardinella brasiliensis showed a lack of parasite species associated pairs, but according to Rohde et al. (1995) this is a common pattern in the majority of studied marine fish. Positive and negative associations between helminth species can provide strong evidence that species interactions exist and act on community structure (Poulin, 2001). But according to Rohde et al. (1995) and Poulin 
(2001), interspecific relationships can only be considered valid when tested under experimental conditions.

\section{References}

AMADO, MAP. and FALAVIGNA, CER., 1996. New species of parasitic copepods of the genus Acusicola (Poecilostomatoida: Ergasilidae) from gill filaments of coastal and freshwater Brazilian fishes, and proposition of Acusicola rogeri $n$. sp. for A. tenax sensu Cressey \& Collette (1970). Hydrobiologia, vol. 324, no. 3, p. 183-193. http://dx.doi.org/10.1007/BF00016390.

BUSH, AO., AHO, J. and KENNEDY, CR., 1990. Ecological versus phylogenetic determinants of helminth parasite community richness. Evolutionary Ecology, vol. 4, no. 1, p. 1-20. http://dx.doi. org/10.1007/BF02270711.

BUSH, AO., LAFFERTY, KD., LOTZ, JM. and SHOSTAK, AW., 1997. Parasitology meets ecology on its own terms: Margolis et al. revisited. The Journal of Parasitology, vol. 83, no. 4, p. 575-583. http://dx.doi.org/10.2307/3284227. PMid:9267395

CONE, DK. and BURT, MDB., 1982. The host specificity of Urocleidus adspectus Mueller, 1936 (Monogenea: Ancyrocephalinae). The Journal of Parasitology, vol. 68, no. 6, p. 1168-1170. http:// dx.doi.org/10.2307/3281117.

FÁBIO, SP., 1988. Sobre três Hemiuridae parasitos de peixes do litoral do Estado do Rio de Janeiro. Arquivos da Universidade Federal Rural do Rio de Janeiro, vol. 7, p. 157-160.

FEIJÓ, LMF., RODRIGUES, HO. and RODRIGUES, SS., 1979. Contribuição ao estudo da fauna helmintológica de sardinhas (Sardinella sp.) do litoral do Estado do rio de Janeiro. Atas da Sociedade de Biologia do Rio de Janeiro, vol. 20, p. 23-27.

FERNANDES, BM. and GOULART, MB., 1989. Dinosoma clupeola sp. n.(Hemiuridae) and Pseudoacanthostomum floridensis Nahhas \& Short, 1965 (Acanthostomidae), digenetic trematodes in Brazilian marine fishes. Memorias do Instituto Oswaldo Cruz, vol. 84, no. 1, p. 103-106. http://dx.doi.org/10.1590/S007402761989000100018

FIGUEIREDO, JL. and MENEZES, NA., 1978. Manual de Peixes marinhos do sudeste do Brasil II Teleostei. São Paulo: Museu de Zoologia. $110 \mathrm{p}$.

GEORGE-NASCIMENTO, MA., 1987. Ecological helminthology of wildlife animal hosts from South America: a literature review and a search for patterns in marine food webs. Revista Chilena de Historia Natural, vol. 60, p. 181-202.

IBAGY, AS. and SINQUE, C., 1985. Distribuição de ovos e larvas de Sciaenidae (Teleostei, Perciformes) na região costeira do Rio Grande do Sul, Brasil. Arquivos de Biologia e Tecnologia, vol. 38 , no. 1, p. 249-270.

KNOFF, M., LUQUE, JL. and AMATO JF., 1997. Community ecology of the metazoan parasites of grey mullets, Mugil platanus (Osteichthyes: Mugilidae) from the littoral of the state of Rio de Janeiro, Brazil. Revista Brasileira de Biologia $=$ Brazilian Journal of Biology, vol. 57, no. 3, p. 441-454. PMid:9430918.

KOHN, A. and BÜHRNHEIM, PF., 1964. Um novo hospedeiro e nova distribuição geográfica para Myosaccium ecaude Montgomery, 1957 (Trematoda, Hemiuridae). Atas da Sociedade de Biologia do Rio de Janeiro, vol. 8, no. 5, p. 50-52.

KOHN, A. and SANTOS, CP., 1988. First report of Mazocroeoides georgei Price, 1936 and Mazocraeoides opisthonema Hargis,
1955 in Brazil with new synonysms (Monogenea, Mazocraeidae). Memórias do Instituto Oswaldo Cruz, vol. 83, no. 4, p. 437-440. http://dx.doi.org/10.1590/S0074-02761988000400007.

LUQUE, JL. and ALVES, DR., 2001. Ecologia das comunidades de metazoários parasitos, do xaréu, Caranx hippos (Linnaeus) e do xerelete, Caranx latus Agassiz (Osteichthyes, Carangidae) do litoral do estado do Rio de Janeiro, Brasil. Revista Brasileira de Zoologia, vol. 18, no. 2, p. 399-410. http://dx.doi.org/10.1590/ S0101-81752001000200011.

LUQUE, JL. and CHAVES, ND., 1999. Ecologia da comunidade de metazoários parasitos da anchova Pomatomus saltator (Linnaeus) (Osteichthyes, Pomatomidae) do litoral do Estado do Rio de Janeiro, Brasil. Revista Brasileira de Zoologia, vol. 16, no. 3, p. 711-723. http://dx.doi.org/10.1590/S0101-81751999000300010.

LUQUE, JL. and POULIN, R., 2004. Use of fish as intermediate hosts by helminth parasites: a comparative analysis. Acta Parasitologica, vol. 49, no. 4, p. 353-361.

LUQUE, JL., AMATO, JFR. and TAKEMOTO, RM., 1996. Comparative analysis of the communities of metazoan parasites of Orthopristis ruber and Haemulon steindachneri (Osteichthyes: Haemulidae) from the southeastern Brazilian littoral: I. structure and influence of the size and sex of hosts. Revista Brasileira de Biologia = Brazilian Journal of Biology, vol. 56, p. 279-292.

LUQUE, JL., VIÑAS, RA., PARAGUASSÚ, AR. and ALVES, DR., 2000. Metazoários Parasitos das sardinhas Sardinella brasiliensis e Harengula clupeola (Osteichthyes, Clupeidae) do litoral do Estado do Rio de Janeiro, Brasil. Revista Universidade Rural - Série Ciências da Vida, vol. 22, supplement, p. 71-76.

MONTÚ, M., 1980. Parasite copepods of southern Brazilian fishes. I. Ergasilus euripedesi n.sp. (Copepoda: Cyclopoidea). Iheringia Serie Zoologia, vol. 56, p. 53-62.

MOREIRA, J., PASCHOAL, F., CEZAR, AD. and LUQUE, JL., 2013. Occurrence of Clavellisa ilishae (Copepoda: Lernaeopodidae) parasitizing herrings (Actinopterygii: Clupeidae) in Brazil. Revista Brasileira de Parasitologia Veterinária, vol. 22, no. 4, p. 616-618. http://dx.doi.org/10.1590/S1984-29612013000400028. PMid:24473893.

PAIVA, MP., 1997. Recursos pesqueiros estuarinos e marinhos do Brasil. Fortaleza: UFC Edições. 286 p.

PALM, HW., 1997. Trypanorhynch Cestodes of commercial fishes from Northeast Brazilian coastal waters. Memorias do Instituto Oswaldo Cruz, vol. 92, no. 1, p. 69-79. http://dx.doi.org/10.1590/ S0074-02761997000100014.

PÉREZ-PONCE DE LEÓN, G., GARCÍA PRIETO, L. and ROSAS VILLA C., 2000. Helmintofauna de Opisthonema libertate y Harengula thrissina (Osteichthyes: Clupeidae) de la bahía de Chamela, Jalisco, México. Revista de Biologia Tropical, vol. 48, no. 4, p. 759-763. PMid:11487924

POLYANSKY, YI.,1961. Ecology of parasites of marine fishes. In DOGIEL, AV., PETRUSHEVSKI, GK. and POLYANSKI, YI. (Eds.). Parasitology of fishes, Edinburgh: Oliver and Boyd. p. 1-47.

POLYANSKY, YI. and BYCHOWSKY, BE., 1963. Parasite fauna of sea fish. Results and perspectives of investigations by Soviet parasitologists on fish parasites in seas of the USSR. Jerusalem: Israel Program for Scientific Translations. p. 187-193.

POULIN, R., 2001. Interactions between species and the structure of helminth communities. Parasitology, vol. 122, supplement, p. S3-S11. http://dx.doi.org/10.1017/S0031182000016991. PMid:11442194. 
POULIN, R., 1993. The disparity between observed and uniform distributions: a new look at parasite aggregation. International Journal for Parasitology, vol. 23, no. 7, p. 937-944. http://dx.doi. org/10.1016/0020-7519(93)90060-C. PMid:8106186.

RODRIGUES, HO., RODRIGUES, SS. and FARIA, Z., 1990. Contribution to the knowledge of the helminthological fauna of vertebrates of Marica, Rio de Janeiro State, Brazil. Memorias do Instituto Oswaldo Cruz, vol. 85, no. 1, p. 115-116. http://dx.doi. org/10.1590/S0074-02761990000100020.

ROHDE, K., HAYWARD, C. and HEAP, M., 1995. Aspects of the ecology of metazoan ectoparasites of marine fishes. International Journal for Parasitology, vol. 25, no. 8, p. 945-970. http://dx.doi. org/10.1016/0020-7519(95)00015-T. PMid:8550295.

RÓZSA, L., REICZIGEL, J. and MAJOROS, G., 2000. Quantifying parasites in samples of hosts. The Journal of Parasitology, vol. 86 , no. 2 , p. 228-232. http://dx.doi.org/10.1645/00223395(2000)086[0228:QPISOH]2.0.CO;2. PMid:10780537.

SANTOS, CP. and KOHN, A., 1992. Description of Cribomazocraes travassosi $\mathrm{n}$. sp. (Monogenea: Mazocraeidae), a fish parasite from the Atlantic Ocean. Memórias do Instituto Oswaldo Cruz, vol. 87, p. 247-250. http://dx.doi.org/10.1590/S0074-02761992000500046.

SCHNEIDER, F. and SCHWINGEL, PR., 1999. Estudo preliminar da ecologia trófica da Sardinella brasiliensis na costa sudeste do Brasil. Brazilian Journal of Aquatic Science and Technology., vol. 3, no. 1, p. 67-72. http://dx.doi.org/10.14210/bjast.v3n1.p67-72.

SILVA, LO., LUQUE, JL., ALVES, DR. and PARAGUASSÚ, AR., 2000. Ecologia da comunidade de metazoários parasitos do peixe-espada Trichiurus lepturus Linnaeus (Osteichthyes, Trichiuridae) do litoral do Estado do Rio de Janeiro, Brasil. Rev. Bras. Zooc., vol. 2, no. 2, p. 115-133.

TAKEMOTO, RM., AMATO, JFR. and LUQUE, JL., 1996. Comparative analysis of the metazoan parasite communities of leatherjackets, Oligoplites palometa, O. saurus, and O. saliens (Osteichthyes:Carangidae) from Sepetiba Bay, Rio de Janeiro, Brazil. Revista Brasileira de Biologia = Brazilian Journal of Biology, vol. 56, no. 4, p. 639-650. PMid:9253203.
TAVARES, LER. and LUQUE, JL., 2004. Community ecology of metazoan parasites of the later juvenile common snook Centropomus undecimalis (Osteichthyes: Centropomidae) from the coastal zone of the State of RIo de Janeiro, Brazil. Revista Brasileira de Biologia $=$ Brazilian Journal of Biology, vol. 64, no. 3A, p. 523-529. http://dx.doi.org/10.1590/S1519-69842004000300015. PMid:15622849.

TAVARES, LE., LUQUE, JL. and BICUDO, AJ. , 2004. Metazoan parasites of Brazilian menhaden Brevoortia aurea (Spix \& Agassiz, 1829) (Osteichthyes: Clupeidae) from the coastal zone of the State of Rio de Janeiro, Brazil. Revista Brasileira de Biologia = Brazilian Journal of Biology, vol. 64, no. 3A, p. 553-554. http:// dx.doi.org/10.1590/S1519-69842004000300019. PMid:15622853.

TRAVASSOS, L., FREITAS, JFT. and BÜHRNHEIM, PF., 1967. Relatório da excursão do Instituto Oswaldo Cruz ao Estado do Espírito Santo em Novembro de 1964. Boletim do Museu de BiologiaMello Leitão, vol. 31, p. 1-54.

VAZ, Z. and PEREIRA, C., 1930. Um novo hemiurídeo parasito de Sardinella aurita. Revista de Biologia e Hygiene, vol. 2, p. 150.

VICENTE, JJ., RODRIGUES, HO. and GOMES, DC. 1985. Nematóides do Brasil. $1^{\text {a }}$ parte: nematóides de peixes. Atas da Sociedade de Biologia do Rio de Janeiro, vol. 25, p. 1-79.

VON ZUBEN, CJ., 1997. Implicações da agregação espacial de parasitas para a dinâmica populacional na interação hospedeiroparasita. Revista de Saúde Pública, vol. 31, no. 5, p. 523-530. http:// dx.doi.org/10.1590/S0034-89101997000600014. PMid:9629733.

WALLET, M. and KOHN, A., 1987. Trematodes parasites de poisson marins du littoral de Rio de Janeiro, Brésil. Memorias do Instituto Oswaldo Cruz, vol. 82, no. 1, p. 21-27. http://dx.doi. org/10.1590/S0074-02761987000100004.

WHITEHEAD, PJP., 1985. An Annotated and IIlustrated Catalogue of the Herrings, Sardines, Pilchards, Sprats, Shads, Anchovies and Wolf-herrings. Part. 1 - Chirocentridae, Clupeidae and Pristigasteridae. Rome: FAO. 303 p. FAO Fisheries Synopsis, no. 125 , vol. 7 .

ZAR, JH., 1996. Biostatistical Analysis. 3rd ed. New Jersey: Prentice-Hall. 662 p. 